\title{
MITIGATING THE RISKS OF ELECTROMAGNETIC RADIATION ON
} WORKERS IN AIR TRAFFIC CONTROL TOWER AT SUHAJ AIRPORT

\author{
M. Abdel Aziz *, M. El Dosoki, A. Shaker**,M.AlFiqi*** andA.Noaman**** \\ *Nuclear and Radiological Control Authority \\ **Faculty of Engineering, Helwan University \\ ****National Air Navigation Services Company NANSC-Civil Aviation \\ **** Radiation Engineering Department, National Center for Radiation Research and Technology, \\ Atomic Energy Authority
}

\section{ABSTRACT:}

One of the most important functions of the Airport Traffic Control Tower (ATCT) is to control and regulate the air traffic and prevent the air craft collisions on the ground and through controlled air field. These services are provided by air traffic controllers using different communication systems and navigation aids. Transmitting antenna of communication system emits electromagnetic waves which have adverse health effects on the workers of the tower. This work is dealing with the electromagnetic radiation effects on workers in Suhaj airport tower by using: simulation process for the antennas at frequencies dedicated for Suhaj airport, on-site measurements, comparing results with standards and a designed questionnaire. The main objective of this research is to mitigate the exposure of workers to hazard and risk from electromagnetic radiation and protect them from its side effects. This study concluded that most of the areas inside the ATCT meet the safe standards except the top roof area where, antenna exist. The questionnaire showed that most of the staff are concerned of EMR in the tower and thought that the EMR has adverse health effect.

Key words: Airport Traffic Control Tower/ Transmitting Antenna/Electromagnetic Waves/Simulation/Questionnaire

\section{INTRODUCTION}

Suhaj Airport Traffic Control Tower

(ATCT) is located in Suhaj Governorate and consists of three basic components: control cab, tower shaft, and base building. The cab is situated at the desired elevation above ground level (AGL) about 30 meters height. The primary tower shaft function is to support the raised cab at the desired elevation.

The base building is normally used to house the equipment necessary to support the operational needs of the ATCT, including space for administrative and training functions and electrical and mechanical facilities. This tower is considered as a source of electromagnetic radiation, this represents a kind of risk on workers $[1,2]$.

This system is established to ensure safety, efficiency, and effectiveness to air traffic system. Its main goal is to keep separation between planes in the zone of the airport to protect planes from collision with 
each other, but it also serves to regulate the aviation of air crafts [3].

The tower equipped with VHF communication systems used by controllers for voice communication with aircraft and with vehicles on the ground, these systems working on air-band frequencies which refers to VHF frequencies 118 to $137 \mathrm{MHz}$, used for navigation and voice communication with aircraft $[4,5,6]$.

The tower's staff faced the communication engineers with the frequently asked question: "Are there adverse health effects on human bodies from operating VHF system in the tower?". This study will try to give answer to this question.

To answer the question, on-site practical measurements must be conducted to determine the electric and magnetic fields strength and the power density outdoor and indoor of the tower, there were different studies have been conducted around the world for RF radiation measurements from a variety of wireless communication sources, the study of Bill P. Curry and Gretchen V. Fleming showed the performing of RF radiation measurement program in Kokomo, Indiana , to determine the sources of Kokomo Hum[7], and the study of Tomasz Dlugosz, Hubert Trzaska presented a comparative analysis of EMF metrology in the near field and in the far field. Measurements in the near field are more difficult and burdened with a considerably larger error than measurements performed in the far field[8] and the study of Soichi Watanabe and Lira Hamada showed the feasibility of compliance evaluation by a relatively simple measurement system such as a small probe for measuring tri-axial isotropic electric fields, and a combination of an antenna and a spectrum analyzer[9], and the study of A K M Fazlul Hoque et al showed that the measurements have been carried out on Bangladesh mobile operators ( stations , centers ), calculations were done for specific absorption rate (SAR) and consequent rise of temperature in human tissues[10].

Potential adverse health effects could be linked to excessive exposure to high-power densities of electromagnetic radiation. These health effects include: Cancer, Tumors, Headaches, Fatigue, Alzheimer's disease and Parkinson's disease[11,12,13]. The health effects of EMR are explained in many studies, the study of Adlina Suleiman et al showed that the comparison of symptoms frequencies and its significance (Chi-square test) between the exposed and not exposed residents from the TELCO tower showed statistical significance $(p<0.05)$ for headache, giddiness, insomnia, loss of memory, diarrhea, mental slowness, reduced reaction time and mood swing[14], and the study of Awn B. Rifai, Majed A. Hakami showed that, the accompanying electromagnetic fields (EMFs) are partially transformed into radiation that affects human health and the potential health hazards of radiation emanating from electric power lines[15], and the study of Kuldip Singh, Younis Muhammad showed that the radiations from Mobile base station towers, cell phones, computers, laptops, TV \& FM towers and microwave ovens etc are very harmful for us and can have adverse effect on 
human body depending on the intensity and frequency of the electromagnetic radiation[16].

Electromagnetic energy is absorbed by the body and deposits energy internally leading to thermal loads and temperature gradients. The measured rate at which energy is absorbed by the human body when exposed to a radio frequency (RF) electromagnetic (EM) field is specific absorption rate (SAR). SAR has been discussed in several studies, A K M Fazlul Hoque et al showed that the Calculations were done for specific absorption rate (SAR) and consequent rise of temperature in human tissues. Maximum power density value (for far field) observed is that for the Bangladesh Link operator (= 1.27x10-6 W/m2). SAR values and the corresponding temperature rise were calculated for the eye, brain and nerve tissues exposed to RF fields, for the general public and occupational workers of Bangladesh for each of the mobile operators [10], and study of M.Usha Rani et al showed the estimation of specific absorption rate of electromagnetic radiations inside human blood, muscle and bone as a function of frequency for different cellular frequency bands. Results are obtained for different conductivities, resistivity values, permeability at those frequency bands for blood, muscle and bone. These results are analyzed and are useful to compare the SAR values with recognized FCC standards[17] , and the study of C. S. Wang, G. X. Shen presented some comparisons and results about the relationships among SAR, different tissues and different resonant frequencies [18].

Safety Guidelines are proposed by several regulating organizations that have set exposure limits maximum permissible exposures (MPEs) and guidelines for RF radiation, such as The Institute of Electrical and Electronic Engineers (IEEE)[19], International Commission on Non-Ionizing Radiation Protection (ICNIRP)[20], The USA Federal Communications Commission (FCC)[21]. Some countries has its own regulations, such as Egyptian Protocol in Egypt[22].

These guidelines are designed to protect both occupational workers and the general public with a very large margin of safety. Most RF safety limits are described in terms of electric and magnetic field strengths as well as in terms of power density.

\section{MATERIALS AND METHODS}

To mitigate the risk, a simulation of electromagnetic sources has been conducted. In addition, measurements of electromagnetic fields and power density have been carried out. The measured values have been compared with the international values of global bodies like ICNIRP, IEEE, FCC and Egyptian protocol. A questionnaire has been designed to know the adverse effects of EMR emitted from the antennas of the ATCT on the workers. The methods had been used are:

1- Computer Simulation Technology (CST) Studio 2014 is the application used to simulate the four antennas of the tower [23]. 
2 - The measurements of power density, electric and magnetic fields were detected by using a handheld EXTECH RF EMF Strength Meter Model 480836 with three-channel (triaxial) measurement probe as shown in figure 1.

It measures all parameters in three directions $X$, Yand $Z$ separately as in the features of instrument, the instrument does not measure total field readinngs[24].

3 - Microsoft Excel Program 2007 used to demonstrate the comparison processes [25].

4- Equations used for calculations are wavelength equation $\lambda$, specific absorption rate equation, power density equation $P_{D}$, field regions equations [26,27,28,29]

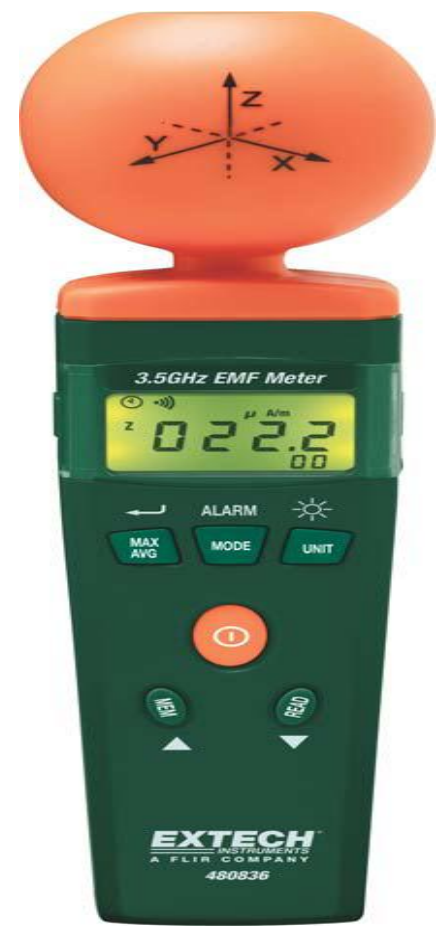

Fig.1 EXTECH EMF strength meter

Wavelength equation

$\lambda=\frac{C}{f}(1)$

Specific Absorption Rate

$S A R=\frac{\sigma E^{2}}{\rho}(2)$

Power Density Equation

Incident Power Density $P_{D}=\frac{E^{2}}{Z_{0}}=\frac{E^{2}}{120 \pi}=\frac{E^{2}}{377}$

Field Regions Equations

Reactive Near Field $\leq 0.62 \times \sqrt{\frac{D^{3}}{\lambda}}$

Radiating Near Field (Frensel Region) $<\frac{2 D^{2}}{\lambda}$

Far Field (Fraunhofer) $\geq \frac{2 D^{2}}{\lambda}$ 


\section{WHERE}

$\lambda$ : Wavelength in meter $\mathbf{m}$

C: Speed of light $=3 \times 10^{8} \mathrm{~m} / \mathrm{s}$

f: Frequency in hertz $\mathbf{H z}$

SAR: Specific Absorption Rate is in (W/kg)

$\sigma$ (sigma): Tissue conductivity $(\mathrm{S} / \mathrm{m})$

E:Electric field strength $(\mathrm{V} / \mathrm{m})$

$\rho$ (rho): The physical density $\left(\mathrm{kg} / \mathrm{m}^{3}\right)$

$S\left(P_{D}\right)$ is in $\left(W / m^{2}\right)$

$\mathrm{Z}_{0}$ : The characteristic impedance of free space equals 377 ohms

R: The distance from the antenna surface

D:Maximum overall dimension of the antenna

5 - Tissue dielectric parameters ( $\sigma$ (sigma), $\rho$ (rho))are computed according to the 4-Cole Model [30].

Methods include simulation of four antennas at dedicated frequency of each one, calculation of SAR and comparison with chosen standards, on-site measurements (outdoor and indoor), calculation of SAR and comparison with chosen standards and questionnaire.

\section{A - SIMULATION}

Computer Simulation Technology (CST) Studio 2014 is the application used to simulating four antennas existing in the tower and emitting radio frequency radiation (RFR) are

1 - Air / Ground frequency is 118.9 $\mathrm{MHz}$ dipole antenna.

2 - Emergency frequency is $121.5 \mathrm{MHz}$ dipole antenna .

3 -Ground / ground frequency is $121.9 \mathrm{MHz}$ dipole antenna .

4 - 2.4 GHz WiFi dipole antenna.

\section{WHERE}

the frequency $118.9 \mathrm{MHz}$ is the operating frequency allocated for Suhaj airport tower only and the frequency 121.5 MHz is the emergency frequency which used in emergency state and the frequency 121.9 $\mathrm{MHz}$ is allocated for communication on the ground of the airport between the tower and all vehicles, workers and planes, while the 2.4 $\mathrm{GHz}$ frequency is the frequency of the WiFi router in the tower.

Simulation parameters are frequency $f$, wavelength $\lambda$, dipole length $L$, radius of dipole $\mathbf{R}$, feedpoint of dipole separation $\mathbf{g}, \mathbf{S}$ Parameter $\left(S_{1,1}\right)$, Directivity, Gain, Efficiency, Electric field E, Magnetic field $H$ and Power Pattern.

Equation (1) used to determine the wave length where the dipole length related to wavelength $\lambda$ and the radius of the dipole related to the dipole length.

The results of each simulated antenna as electric field, magnetic field, power density and antenna parameters were tabulated. Electric field, magnetic field and power density compared with standards of ICNIRP, IEEE, FCC and Egyptian protocol. After that, the specific absorption rate (SAR) and power density $P_{D}$ will be calculated using equations $(2,3)$ respectively and field regions will be calculated by equations $(4,5,6)$.

SAR is calculated for average brain, average skull, and average muscle at the four frequencies and will be compared with SAR standards of using the results and compared with standards bodies mentioned above. 
B- On-Site Measurements divided into

Outdoor and Indoor measurements where accomplished by using a handheld EXTECH RF EMF Strength Meter Model 480836.

The results of on-site measurement results will be tabulated and compared with the standards (ICNIRP, IEEE, FCC and Egyptian Protocol).

B-1 Outdoor Measurements performed in three directions $\mathrm{X}, \mathrm{Y}$ and $\mathrm{Z}$ for ATC tower rooftop and out of tower at distances of $3 \mathrm{~m}$, $10 \mathrm{~m}$ and $30 \mathrm{~m}$ from the building, calculation of SAR and comparing the results with standards mentioned above to demonstrate that the areas mentioned above are safe or risky.

B-2 Indoor measurements performed in two directions $\mathrm{X}$ and $\mathrm{Y}$ for the tower $\mathrm{CAB}$, equipment room, air nav. sys. engineering office, comm. administration office, the tower reception and the walkthrough in the tower building where the measurements were taken as: reactive near field of WiFi router at $0.02 \mathrm{~m}$ from the beginning point of walkthrough, near field of $\mathrm{WiFi}$ router at $\mathbf{0 . 0 4 m}$ from the beginning point of walk -through, Far field of WiFi router at $1 \mathrm{~m}$ from the beginning point of walkthrough, middle point (at10m from the beginning) of walkthrough and end point Figure 2 ATC tower facility component (at20m from the beginning) of walkthrough. Calculation of SAR and comparing the results with standards mentioned above to demonstrate that the areas mentioned above are safe or risky, figure $\mathbf{2}$ demonstrates the air control tower facility components: (tower where the CAB mounted and the rooftop, basebuilding where rooms, administrative offices and walkthrough) .

\section{RESULTS AND DISCUSSIONS}

The measurements showed that both risky and safe areas in the tower and outside it with related SAR calculations comparisons charts. This study shows two examples one for risky area and the other for safe area 


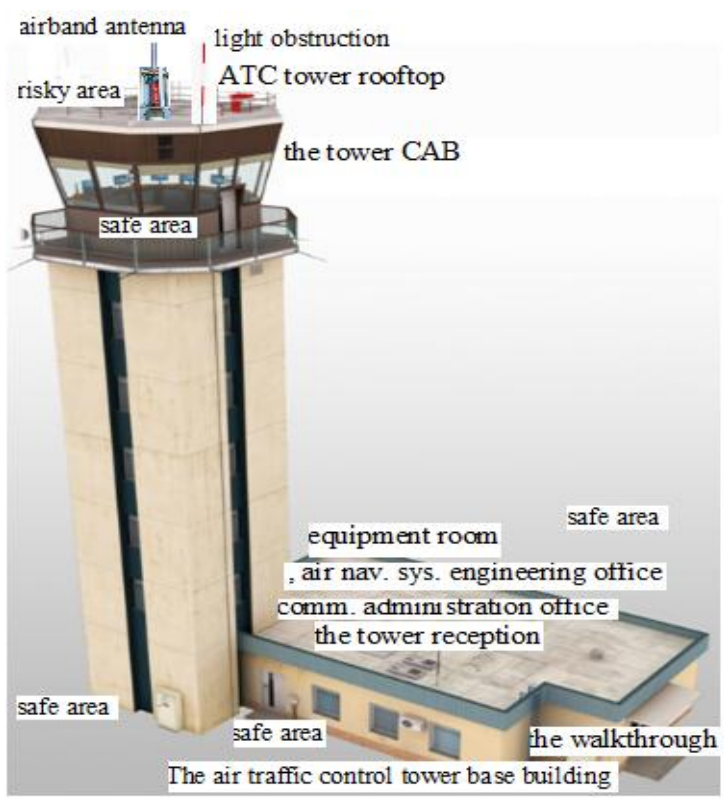

The air traffic control tower facility

(Fig.2 ATC tower facility)

where the measured parameters are:

$E_{\max }$ (Maximum Electric field strength) $\mathrm{V} / \mathrm{m}$

$E_{\text {ave }}$ (Average Electric field strength) $\mathrm{V} / \mathrm{m}$

$\mathbf{E}_{\text {max ave }}$ (Maximum Average Electric field strength) $\mathrm{V} / \mathrm{m}$

$\mathbf{H}_{\max }$ (Maximum Magnetic field strength) $\mathrm{A} / \mathrm{m}$

$\mathrm{H}_{\text {ave }}$ (Average Magnetic field strength) $\mathrm{A} / \mathrm{m}$

$\mathbf{H}_{\text {max ave }}$ (Maximum Average Magnetic field strength) $\mathrm{A} / \mathrm{m}$

$P_{\max }$ (Maximum Power Density ) $\left(\mathrm{W} / \mathrm{m}^{2}\right)$

$P_{\text {ave }}$ (Average Power Density) $\left(\mathrm{W} / \mathrm{m}^{2}\right)$

$P_{\max }$ ave (Maximum Average Power Density) $\left(\mathrm{W} / \mathrm{m}^{2}\right)$.

Example 1, Risky Area

Outdoor Measurement, SAR calculation and Comparisons tables for rooftop of the ATC tower in $\mathrm{X}, \mathrm{Y}$ and $\mathrm{Z}$ directions in Near Field Region are tabulated as following :

1- Table 1, Near Field Region Measurements.

2- Table 2, Near Field Region SAR calculations.

3 -Table 3, Near Field Region $E_{\max }, H_{\max }, P_{\max }$ / Standards Comparison Chart.

4 -Table 4, Near Field Region SAR calculation comparison chart.

Note: The values in tables of comparisons 3,4,are expressed in terms of logarithms to enabling comparison process. 
Table 1 Near field region measurements

\begin{tabular}{|c|c|c|c|c|c|c|c|c|}
\hline \multirow{11}{*}{$\begin{array}{l}\text { Near Field } \\
\text { Region } \\
\text { Measuremen } \\
\text { ts In X - } \\
\text { Direction }\end{array}$} & \multicolumn{3}{|c|}{ EMR Parameters } & \multicolumn{5}{|c|}{$\begin{array}{c}\text { Limits of RMS Values of Electric and } \\
\text { Magnetic Fields, } \\
\text { Power Density }(S)\left(\mathrm{W} / \mathrm{m}^{2}\right) \text { in Controlled } \\
\text { Environments }\end{array}$} \\
\hline & \multirow[t]{2}{*}{$E_{\max }$} & \multirow[t]{2}{*}{$E_{\text {ave }}$} & \multirow[t]{2}{*}{$E_{\text {max ave }}$} & $\begin{array}{l}\text { ICNIR } \\
\text { P } \\
\end{array}$ & IEEE & \multicolumn{2}{|c|}{ FCC } & $\begin{array}{l}\text { Egy. } \\
\text { code }\end{array}$ \\
\hline & & & & \multicolumn{5}{|c|}{$(\boldsymbol{E})(\mathbf{V} / \mathbf{m})$} \\
\hline & $534.2 \mathrm{mV} / \mathrm{m}$ & $\begin{array}{l}11.7 \\
m V / m\end{array}$ & $12.12 \mathrm{~V} / \mathrm{m}$ & 61 & 61.4 & \multicolumn{2}{|l|}{61.4} & --- \\
\hline & \multicolumn{3}{|c|}{ Percentage Value of $E_{\text {max }} \Rightarrow$} & 0.8757 & 0.87 & \multicolumn{2}{|l|}{0.87} & --- \\
\hline & $H_{\max }$ & $H_{\text {ave }}$ & $H_{\text {max ave }}$ & \multicolumn{5}{|c|}{$(\boldsymbol{H}) \quad(\mathbf{A} / \mathbf{m})$} \\
\hline & $230.2 m A / m$ & $22 \mu \mathrm{A} / \mathrm{m}$ & $33.4 \mu A / m$ & 0.16 & 0.163 & \multicolumn{2}{|l|}{0.163} & --- \\
\hline & \multicolumn{3}{|c|}{ Percentage Value of $H_{\max } \Rightarrow$} & 143.875 & $\begin{array}{l}141.22 \\
6\end{array}$ & \multicolumn{2}{|l|}{141.226} & --- \\
\hline & $P_{\max }$ & $P_{\text {ave }}$ & $P_{\text {max ave }}$ & \multicolumn{5}{|c|}{ power density $(S)\left(\mathrm{W} / \mathrm{m}^{2}\right)$} \\
\hline & $22.67 \mathrm{~W} / \mathrm{m}^{2}$ & $\begin{array}{l}0.2 \\
\mu W / m^{2}\end{array}$ & $\begin{array}{l}8.74 \\
W / m^{2} \\
\end{array}$ & 10 & 10 & \multicolumn{2}{|l|}{10} & 4 \\
\hline & \multicolumn{3}{|c|}{ Percentage Value of $P_{\max } \Longrightarrow$} & 226.7 & 226.7 & \multicolumn{2}{|l|}{226.7} & $\begin{array}{l}566.7 \\
5 \\
\end{array}$ \\
\hline \multirow{9}{*}{$\begin{array}{l}\text { Near Field } \\
\text { Region } \\
\text { Measuremen } \\
\text { ts In Y - } \\
\text { Direction }\end{array}$} & $E_{\text {max }}$ & $E_{\text {ave }}$ & $E_{\text {max ave }}$ & \multicolumn{5}{|c|}{$(E) \quad(\mathbf{V} / \mathbf{m})$} \\
\hline & $131.1^{a} \mathrm{~V} / \mathrm{m}$ & $\begin{array}{l}11.7 \\
m V / m\end{array}$ & $118.2 \mathrm{~V} / \mathrm{m}$ & 61 & 61.4 & 61. & & --- \\
\hline & \multicolumn{3}{|c|}{ Percentage Value of $E_{\max } \Rightarrow$} & 214.918 & 213.518 & 213 & & --- \\
\hline & $H_{\max }$ & $H_{\text {ave }}$ & $H_{\text {max ave }}$ & \multicolumn{5}{|c|}{$(\boldsymbol{H}) \quad(\mathbf{A} / \mathbf{m})$} \\
\hline & $284.2 m A / m$ & $\begin{array}{l}35.5 \\
\mu A / m\end{array}$ & $\begin{array}{l}132.5 \\
m A / m\end{array}$ & 0.16 & 0.163 & \multicolumn{2}{|l|}{0.163} & --- \\
\hline & \multicolumn{3}{|c|}{ Percentage Value of $\boldsymbol{H}_{\max } \Rightarrow$} & $\mathbf{1 7 7 . 8 2 5}$ & 174.356 & \begin{tabular}{l|l|}
174.35 \\
\end{tabular} & & --- \\
\hline & $P_{\max }$ & $P_{\text {ave }}$ & $P_{\text {max ave }}$ & \multicolumn{5}{|c|}{ power density $(S)\left(\mathrm{W} / m^{2}\right)$} \\
\hline & $16.3 \mathrm{~W} / \mathrm{m}^{2}$ & $\begin{array}{l}0.1 \\
\mu W / m^{2}\end{array}$ & $\begin{array}{l}8.296 \\
W / m^{2} \\
\end{array}$ & 10 & 10 & \begin{tabular}{l|l|}
10 \\
\end{tabular} & 4 & \\
\hline & \multicolumn{3}{|c|}{ Percentage Value of $P_{\max } \Rightarrow$} & 163 & 163 & 163 & & \\
\hline \multirow{9}{*}{$\begin{array}{l}\text { Near Field } \\
\text { Region } \\
\text { Measuremen } \\
\text { ts In Z - } \\
\text { Direction }\end{array}$} & $E_{\max }$ & $E_{\text {ave }}$ & $E_{\text {max ave }}$ & $(\boldsymbol{E})$ & & & & \\
\hline & $56.25 \mathrm{~V} / \mathrm{m}$ & $\begin{array}{l}5.8 \\
m V / m\end{array}$ & $6.7 \mathrm{~V} / \mathrm{m}$ & 61 & 61.4 & 61.4 & - & \\
\hline & \multicolumn{3}{|c|}{ Percentage Value of $E_{\max } \Rightarrow$} & 92.213 & 91.612 & 91.612 & - & \\
\hline & $H_{\max }$ & $H_{\text {ave }}$ & $H_{\max a v e}$ & \multicolumn{5}{|c|}{$(\boldsymbol{H}) \quad(\mathbf{A} / \mathbf{m})$} \\
\hline & $274.6 m A / m$ & $\begin{array}{l}24.4 \\
\mu A / m\end{array}$ & $\begin{array}{l}103.1 \\
m A / m\end{array}$ & 0.16 & 0.163 & 0.163 & -- & \\
\hline & Percentage Valuc & of $H_{\max }$ & & 171.625 & 168.466 & \begin{tabular}{|l|l}
168.46 \\
6
\end{tabular} & $\cdots$ & \\
\hline & $P_{\max }$ & $P_{\text {ave }}$ & $P_{\text {max ave }}$ & power d & nsity $(S)$ & $\left.N / m^{2}\right)$ & & \\
\hline & $16.79 \mathrm{~W} / \mathrm{m}^{2}$ & $\begin{array}{l}0.1 \\
\mu W / m^{2}\end{array}$ & $8.4 \mathrm{~W} / \mathrm{m}^{2}$ & 10 & 10 & 10 & 4 & \\
\hline & Percentage Valuc & of $P_{\max }$ & & 167.9 & 167.9 & 167.9 & & \\
\hline
\end{tabular}


Table 2 Near field region (SAR calculation and comparison)

\begin{tabular}{|c|c|c|c|c|c|}
\hline \multicolumn{2}{|c|}{ tissue dielectrics } & \multirow{3}{*}{$\begin{array}{c}\text { measured } \\
E_{\max }\end{array}$} & \multirow{3}{*}{$\begin{array}{l}\text { SAR calculated } \\
\text { value }\end{array}$} & \multirow{2}{*}{\multicolumn{2}{|c|}{$\begin{array}{c}\text { SAR Limits of INCIRP, IEEE }=2 \mathrm{~W} / \mathrm{Kg} \& \\
\text { FCC }=1.6 \mathrm{~W} / \mathrm{Kg} \\
\text { (pct) of SAR calculated }\end{array}$}} \\
\hline \multirow[t]{2}{*}{ conductivity $\sigma$} & \multirow[t]{2}{*}{ density $\rho$} & & & & \\
\hline & & & & $\begin{array}{c}2.0 \mathrm{~W} / \mathrm{kg} \text { averaged } \\
\text { over } 10 \mathrm{~g} \text { of tissue }\end{array}$ & $\begin{array}{c}1.6 \mathrm{~W} / \mathrm{kg} \text { averaged } \\
\text { over } 1 \mathrm{~g} \text { of tissue }\end{array}$ \\
\hline \multicolumn{6}{|c|}{ Rooftop of ATC Tower : Near Field Region In X - Direction } \\
\hline \multicolumn{2}{|c|}{ Brain } & \multirow{6}{*}{$\begin{array}{c}534.2 \\
m V / m\end{array}$} & \multirow{2}{*}{0.00012733} & \multirow{2}{*}{$0.00637 \%$} & \multirow{2}{*}{$0.00796 \%$} \\
\hline 0.459574 & 1030 & & & & \\
\hline \multicolumn{2}{|l|}{ Skull } & & \multirow{2}{*}{$18.89 \mu W / k g$} & \multirow{2}{*}{$0.000944 \%$} & \multirow{2}{*}{$0.00118 \%$} \\
\hline 0.122461 & 1850 & & & & \\
\hline \multicolumn{2}{|c|}{ Muscle } & & \multirow{2}{*}{0.000203} & \multirow{2}{*}{$0.0101 \%$} & \multirow{2}{*}{$0.0126 \%$} \\
\hline $\mathbf{0 . 7 3 9 1 8 7}$ & 1040 & & & & \\
\hline \multicolumn{6}{|c|}{ Rooftop of ATC Tower : Near Field Region In Y - Direction } \\
\hline \multicolumn{2}{|c|}{ Brain } & \multirow{6}{*}{$131.1 \mathrm{~V} / \mathrm{m}$} & \multirow{2}{*}{7.6887} & \multirow{2}{*}{$383.4366 \%$} & \multirow{2}{*}{ 479.296 \% } \\
\hline 0.459574 & 1030 & & & & \\
\hline \multicolumn{2}{|c|}{ Skull } & & \multirow{2}{*}{1.1377} & \multirow{2}{*}{$56.885 \%$} & \multirow{2}{*}{$71.11 \%$} \\
\hline 0.122461 & 1850 & & & & \\
\hline \multicolumn{2}{|c|}{ Muscle } & & \multirow{2}{*}{12.216} & \multirow{2}{*}{$610.7962 \%$} & \multirow{2}{*}{$763.495 \%$} \\
\hline 0.739187 & 1040 & & & & \\
\hline & & ftop of ATC & wer : Near Field & ion In Z - Direction & \\
\hline Bra & & & 10110 & 705007 & 002107 \\
\hline 0.459574 & 1030 & & 1.4118 & $70.59 \%$ & $08.24 \%$ \\
\hline Sku & & $5625 \mathrm{~V} / \mathrm{m}$ & 02094 & $10.47 \%$ & $13.09 \%$ \\
\hline 0.122461 & 1850 & & & & \\
\hline Mus & & & 24889 & $112444 \%$ & $140555 \%$ \\
\hline 0.739187 & 1040 & & 2.4889 & $112.444 \%$ & \\
\hline
\end{tabular}

According to tables 1, 2 of near field region (measurements and SAR calculations) as following:

a. In X - direction

It is obviously that the value of $E_{\text {max }}$ is too small in comparing with standards limits and values of $H_{\max }$ and $P_{\max }$ are too large in comparing with standards limits, so it is a risky area

It is obviously that the SAR values are too small in comparing with the standards limits.

b. In Y - direction

The values of $E_{\max }, H_{\max }$ andP $P_{\max }$ are too large than the limits of standards, so it is a risky area. SAR value for average brain and average muscle are too large than limits of all standards, so it is a risky area. SAR value for average skull is within the limits.

c. In $\mathrm{Z}$ - direction
It is obviously that the value of $E_{\text {max }}$ within the standards limits, while $H_{\text {max }}$ and $P_{\text {max }}$ values are too large comparing with the standards limits.SAR values for average brain and average skull are within the limits, while SAR value for average muscle comparing with standards is very greater than the limits of these standards, so it is a risky area, since the rooftop area is risky, it is needed to control the exposure and protect the workers. The exposure is controlled by two types : engineering controls which include shielding and using interlocks as applicable; filtering, and waveguides below cutoff. RF protective clothing may be used in antenna zone, administrative controls which include RF safety training, increasing distance, controlling exposure time, restricting access, and using warning signs. 
Table 3 Near field region $\left(E_{\max }, H_{\max }, P_{\max } /\right.$ standards comparison chart)

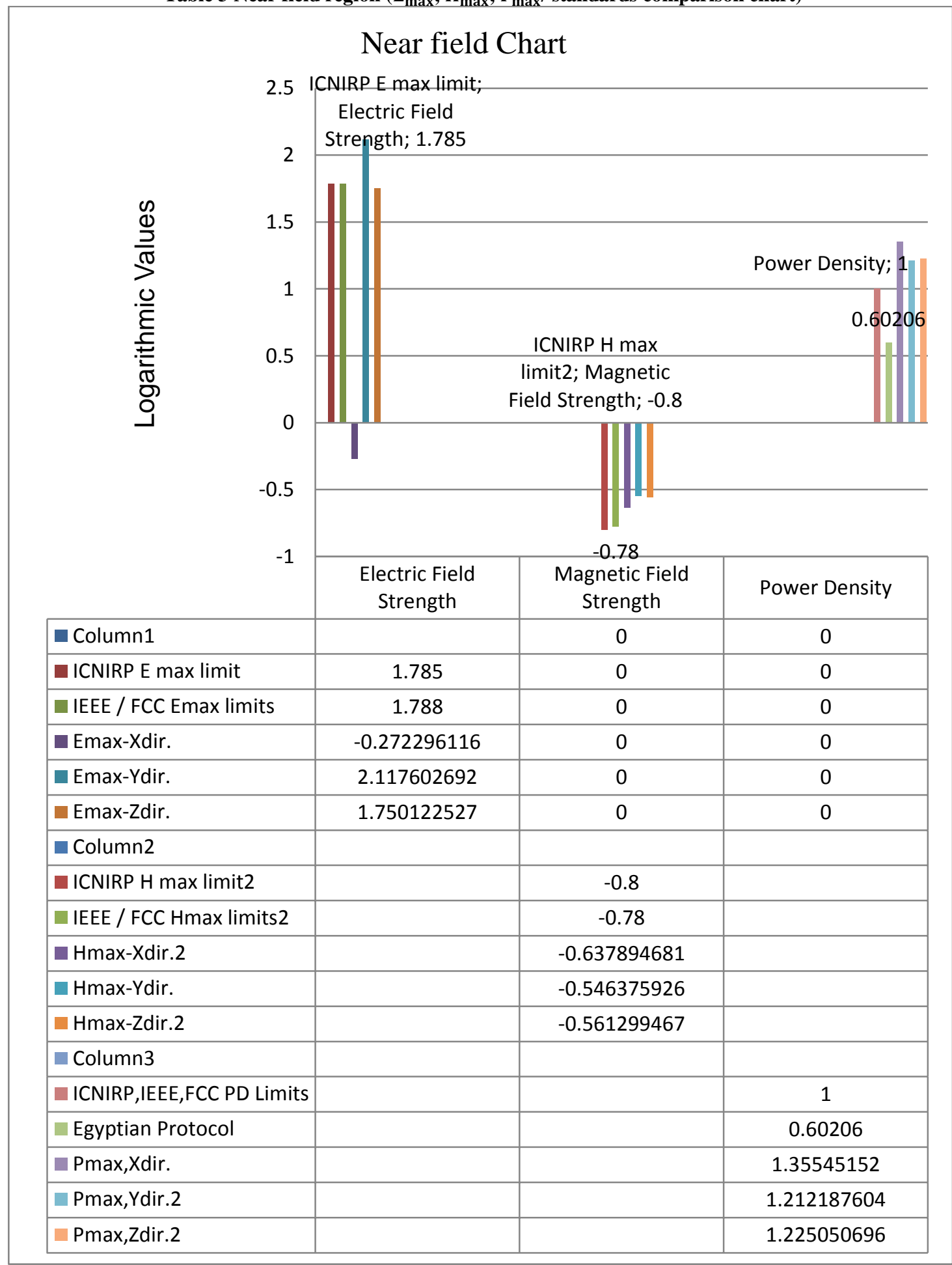

As shown in the chart above, values of $E_{\max }$ in $Y$ - direction exceeds the limits, $H_{\max }$ in $X, Y$ and $Z$ directions exceed the limits also, while the $\mathbf{P}_{\max }$ in all directions within the Egyptian limits but the other limits ICNIRP, IEEE, FCC exceeded. The rooftop is a risky area because the safety limits are exceeded, so, the access in this area is restricted and the individuals authorized to enter this area who are aware of the potential for exposure as a concomitant of employment and perform various maintenance works, they must follow the instructions in safety programs and using the personal protection equipments . 
Table 4 Near field region (SAR calculation comparison chart)

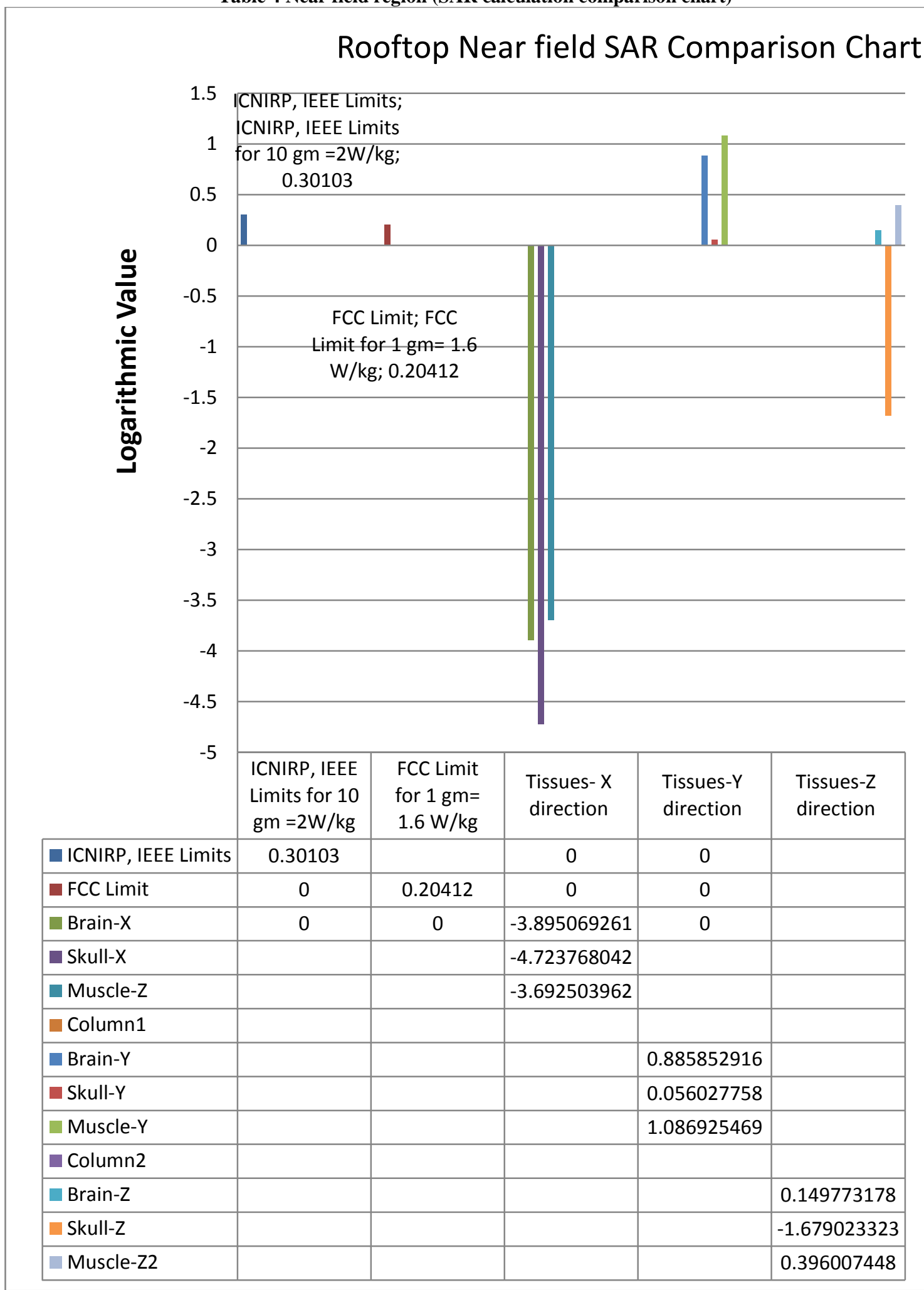

As shown in the chart above, values of brain and muscle in $Y$ direction and muscle in $Z$-direction exceed the limits, on the other hand the values in all directions within the limits or less greater than the limits. 


\section{Example 2, Safe area}

Indoor Measurement, SAR calculations and Comparisons tables for the Tower CAB are tabulated as following:

5- Table 5, the Tower CAB Measurements.
6- Table 6, the Tower CAB SAR calculations.

7- Table 7, the Tower CAB $E_{\max }, H_{\max }, P_{\max }$ / Standards Comparison Chart

8- Table 8, the Tower CAB SAR calculation comparison chart.

Table 5 Tower CAB measurements

\begin{tabular}{|c|c|c|c|c|c|c|c|}
\hline \multirow{11}{*}{$\begin{array}{l}\text { EMR } \\
\text { Measurement } \\
\text { s In X - } \\
\text { Direction }\end{array}$} & \multicolumn{3}{|c|}{ EMR Parameters } & \multicolumn{4}{|c|}{ Standards and Regulations } \\
\hline & \multirow{2}{*}{$E_{\max }$} & \multirow[t]{2}{*}{$E_{\text {ave }}$} & \multirow[t]{2}{*}{$E_{\text {max ave }}$} & ICNIRP & $\begin{array}{l}\text { IEEE } \\
\left(\mathbf{W} / \boldsymbol{m}^{2}\right)\end{array}$ & FCC & $\begin{array}{l}\text { Egypt } \\
\text { code }\end{array}$ \\
\hline & & & & \multicolumn{4}{|c|}{$(\boldsymbol{E}) \quad(\mathbf{V} / \mathbf{m})$} \\
\hline & $\begin{array}{l}561.9 \\
m V / m\end{array}$ & $10 \mathrm{mV} / \mathrm{m}$ & $\begin{array}{l}187.3 \\
m V / m\end{array}$ & 61 & 61.4 & 61.4 & --- \\
\hline & \multicolumn{3}{|c|}{ Percentage Value of $E_{\max } \Rightarrow$} & $0.92 \%$ & $0.915 \%$ & $0.915 \%$ & --- \\
\hline & $H_{\max }$ & $H_{\text {ave }}$ & $H_{\text {max ave }}$ & \multicolumn{4}{|c|}{$(\boldsymbol{H}) \quad(\mathrm{A} / \mathbf{m})$} \\
\hline & $1.9 m A / m$ & $\begin{array}{l}15.3 \\
\mu A / m\end{array}$ & $\begin{array}{l}757.5 \\
\mu A / m\end{array}$ & 0.16 & 0.163 & 0.163 & --- \\
\hline & \multicolumn{3}{|c|}{ Percentage Value of $\boldsymbol{H}_{\max } \Rightarrow$} & $0.0031 \%$ & $\mathbf{0 . 0 0 3} \%$ & $0.003 \%$ & --- \\
\hline & $P_{\max }$ & $P_{\text {ave }}$ & $P_{\text {max ave }}$ & \multicolumn{4}{|c|}{ power density $(S)\left(\mathrm{W} / \mathrm{m}^{2}\right)$} \\
\hline & $793 \mu W / m^{2}$ & $\begin{array}{l}0.1 \\
\mu W / m^{2}\end{array}$ & $\begin{array}{l}132.3 \\
\mu W / m^{2}\end{array}$ & 10 & 10 & 10 & 4 \\
\hline & \multicolumn{3}{|c|}{ Percentage Value of $P_{\max } \Longrightarrow$} & $\begin{array}{l}\mathbf{0 . 0 0 7 9 3} \\
\%\end{array}$ & $\begin{array}{l}\text { 0.00793 } \\
\%\end{array}$ & $\begin{array}{l}\mathbf{0 . 0 0 7 9 3} \\
\%\end{array}$ & $\begin{array}{l}\mathbf{0 . 0 1 9 8 2 5} \\
\%\end{array}$ \\
\hline \multirow{9}{*}{$\begin{array}{l}\text { EMR } \\
\text { Measurement } \\
\text { s In Y - } \\
\text { Direction }\end{array}$} & $E_{\max }$ & $E_{\text {ave }}$ & $E_{\text {max ave }}$ & $(\boldsymbol{E}) \quad(\mathbf{V} / \mathbf{n}$ & & & \\
\hline & $\begin{array}{l}401.5 \\
m V / m\end{array}$ & $\begin{array}{l}5.8 \\
m V / m \\
\end{array}$ & $6.7 \mathrm{mV} / \mathrm{m}$ & 61 & 61.4 & 61.4 & --- \\
\hline & \multicolumn{3}{|c|}{ Percentage Value of $E_{\max } \Rightarrow$} & $0.6581 \%$ & $0.6539 \%$ & $0.6539 \%$ & --- \\
\hline & $H_{\max }$ & $H_{\text {ave }}$ & $H_{\text {max ave }}$ & \multicolumn{4}{|c|}{$(\boldsymbol{H}) \quad(\mathbf{A} / \mathbf{m})$} \\
\hline & $1.249 \mathrm{~mA} / \mathrm{m}$ & $\begin{array}{l}17.7 \\
\mu A / m\end{array}$ & $26.5 \mu A / m$ & 0.16 & 0.163 & 0.163 & --- \\
\hline & \multicolumn{3}{|c|}{ Percentage Value of $H_{\max } \Rightarrow$} & $0.780 \%$ & $0.766 \%$ & $0.766 \%$ & --- \\
\hline & $P_{\max }$ & $P_{\text {ave }}$ & $P_{\text {max ave }}$ & \multicolumn{4}{|c|}{ power density $(S)\left(\mathrm{W} / m^{2}\right)$} \\
\hline & $\begin{array}{l}576.5 \\
\mu W / m^{2}\end{array}$ & $\begin{array}{l}0.1 \\
\mu W / m^{2}\end{array}$ & $\begin{array}{l}0.9 \\
\mu W / m^{2}\end{array}$ & 10 & 10 & 10 & 4 \\
\hline & \multicolumn{3}{|c|}{ Percentage Value of $\boldsymbol{P}_{\max } \Rightarrow$} & $\begin{array}{l}\mathbf{0 . 0 0 5 6 7} \\
\%\end{array}$ & $\begin{array}{l}\mathbf{0 . 0 0 5 6 7} \\
\%\end{array}$ & $\begin{array}{l}\mathbf{0 . 0 0 5 6 7} \\
\%\end{array}$ & $0.01418 \%$ \\
\hline
\end{tabular}


Table 6 Tower CAB (SAR calculation and comparison)

\begin{tabular}{|c|c|c|c|c|c|}
\hline \multicolumn{2}{|c|}{ tissue dielectrics } & \multirow{2}{*}{$\begin{array}{c}\text { measured } \\
E_{\max }\end{array}$} & \multirow{2}{*}{$\begin{array}{c}\text { SAR calculated } \\
\text { value } W / K g\end{array}$} & \multicolumn{2}{|c|}{$\begin{array}{c}\text { SAR Limits of INCIRP, IEEE }=2 \mathrm{~W} / \mathrm{Kg} \& \\
\text { FCC }=1.6 \mathrm{~W} / \mathrm{Kg} \\
\text { (pct) of SAR calculated }\end{array}$} \\
\hline conductivity $\sigma$ & density $\rho$ & & & $\begin{array}{c}2.0 \mathrm{~W} / \mathrm{kg} \text { averaged } \\
\text { over } 10 \mathrm{~g} \text { of tissue }\end{array}$ & $\begin{array}{c}1.6 \mathrm{~W} / \mathrm{kg} \text { averaged } \\
\text { over } 1 \mathrm{~g} \text { of tissue }\end{array}$ \\
\hline \multicolumn{6}{|c|}{ Tower CAB SAR Calculations In X - Direction } \\
\hline \multicolumn{2}{|c|}{ Brain } & \multirow{6}{*}{$561.9 \mathrm{mV} / \mathrm{m}$} & \multirow{2}{*}{0.0001409} & \multirow{2}{*}{$0.007044 \%$} & \multirow{2}{*}{$0.0088 \%$} \\
\hline 0.459574 & 1030 & & & & \\
\hline \multicolumn{2}{|l|}{ Skull } & & & & \\
\hline 0.122461 & 1850 & & $20 \mu W / k g$ & $0.001045 \%$ & $0.00125 \%$ \\
\hline \multicolumn{2}{|c|}{ Muscle } & & \multirow{2}{*}{0.0002244} & \multirow{2}{*}{$0.01122 \%$} & \multirow{2}{*}{$0.014025 \%$} \\
\hline 0.739187 & 1040 & & & & \\
\hline \multicolumn{6}{|c|}{ Tower CAB SAR Calculations In Y - Direction } \\
\hline \multicolumn{2}{|c|}{ Brain } & \multirow{6}{*}{$401.5 \mathrm{mV} / \mathrm{m}$} & \multirow{2}{*}{$71.93 \mu W / k g$} & \multirow{2}{*}{$0.003596 \%$} & \multirow{2}{*}{$0.0045 \%$} \\
\hline 0.459574 & 1030 & & & & \\
\hline \multicolumn{2}{|l|}{ Skull } & & \multirow{2}{*}{$10.67 \mu W / k g$} & \multirow{2}{*}{$0.0005335 \%$} & \multirow{2}{*}{$0.00067 \%$} \\
\hline 0.122461 & 1850 & & & & \\
\hline \multicolumn{2}{|c|}{ Muscle } & & \multirow{2}{*}{0.0001145} & \multirow{2}{*}{$0.005725 \%$} & \multirow{2}{*}{$0.00716 \%$} \\
\hline 0.739187 & 1040 & & & & \\
\hline
\end{tabular}

According to tables 5 and 6 of the Tower CAB measurements and SAR calculations as following:

a. In $\mathrm{X}$ - direction

It is obviously that the values of $E_{\max }, H_{\max }$ and $P_{\text {max }}$ are too small in comparing with standards limits, so it is a safe area. It is obviously that the SAR values are too small in comparing with standards limits, so it is a safe area.

b. In Y - direction

The values of $E_{\max }, H_{\max }, P_{\max }$ are too small comparing with the limits of standards, so it is a safe area. It is obviously that all SAR values are too small comparing with the limits of all standards, so it is a safe area. 
Table 7 Tower CAB ( $E_{\max }, H_{\max }, P_{\max } /$ Standards Comparison Chart)

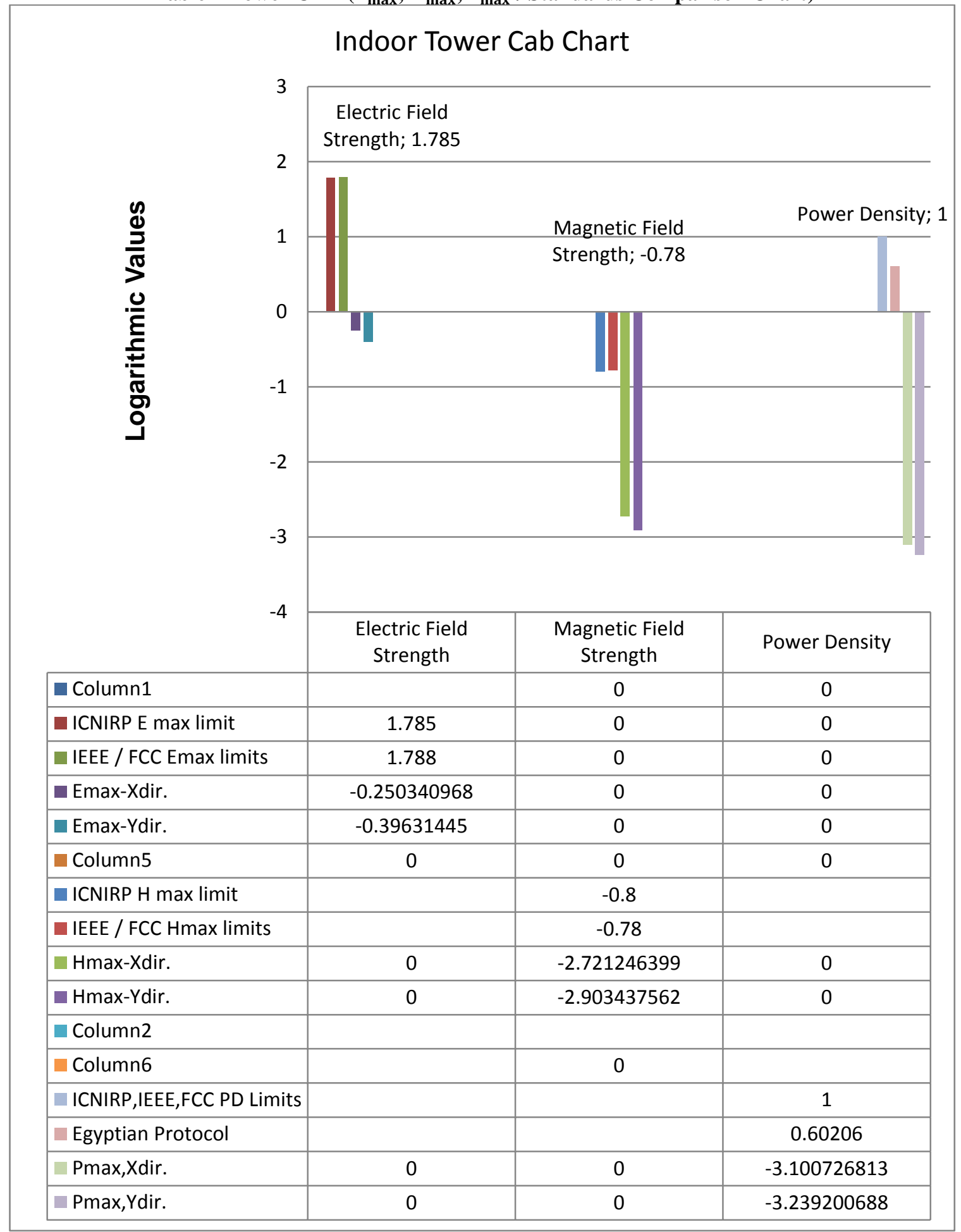

As shown in the chart above the values are less than the limits 
Table 8 Tower CAB (SAR calculation comparison chart)

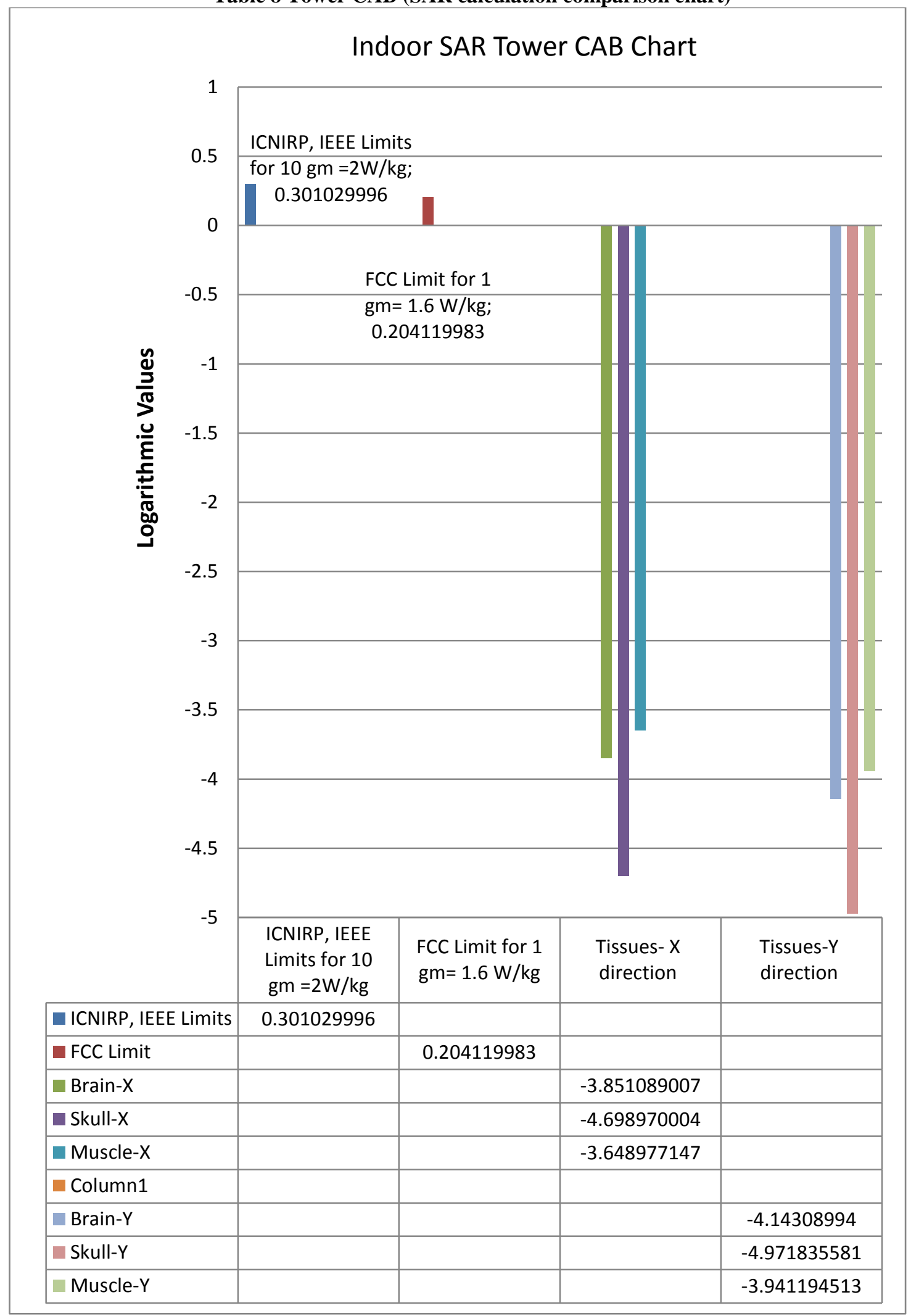

As shown in the chart above the values are less great than the limits 


\section{C - QUESTIONNAIRE}

In response to staff concerning, questionnaire survey was performed and based on form as following:

1- Dividing the staff of 60 persons in five specialized working groups WGs depending on the work nature as following

WG1: Air Traffic Controllers, WG2: Communication engineers, WG3: Maintenance engineers,

WG4: Air Operations Officers, WG5: Administrative Employees.
2- Asking all the staff of 60 persons four questions as following

Q1: Are you concerning from EMR in your workplace?

Q2: What are the symptoms you feel when you are in a tower?

Q3: Do you have awareness about International standards and guidelines controlling the EMR?

Q4: Do you have awareness about Egyptian protocol?

Note : the kinds of effects are thermal effects and nonthermal effects

Tables 9, 10 demonstrate the questionnaire and the comparisons.

Table 9 Questionnaire results

\begin{tabular}{|c|c|c|c|c|c|c|}
\hline & \multicolumn{2}{|c|}{ Total Staff } & Q1 & Q2 & Q3 & Q4 \\
\hline Staff & 60 & & --- & --- & --- & --- \\
\hline WG1 & 12 & $20 \%$ & $12=100 \%$ of WG1 & $12=100 \%$ of WG1 & $6=50 \%$ of WG1 & $\mathbf{0}$ \\
\hline WG2 & 10 & $16.667 \%$ & $10=100 \%$ of WG2 & $10=100 \%$ of WG2 & $8=80 \%$ of WG2 & $\begin{array}{c}2=20 \% \text { of } \\
\text { WG } 2\end{array}$ \\
\hline WG3 & 12 & $20 \%$ & $12=100 \%$ of $\mathrm{WG} 3$ & $12=100 \%$ of WG3 & $\mathbf{0}$ & 0 \\
\hline WG4 & 12 & $20 \%$ & $12=100 \%$ of WG4 & $12=100 \%$ of WG4 & $\mathbf{0}$ & $\mathbf{0}$ \\
\hline WG5 & 14 & $23.333 \%$ & $6=42.86 \%$ ofWG5 & $3=21.43 \%$ of WG5 & $\mathbf{0}$ & $\mathbf{0}$ \\
\hline$(p c t) r$ & & $100 \%$ & $86.67 \%$ & $81.67 \%$ & $23.33 \%$ & $3.33 \%$ \\
\hline
\end{tabular}

The results show that $86.666 \%$ of staff are concerned of EMR in the tower, $81.666 \%$ of staff are thought that the EMR has adverse health effect, $23.333 \%$ of staff has awareness of Int. standards and $3.333 \%$ of staff has awareness of Egyptian protocol.

The study recommends modifying and upgrading Egyptian protocols and raising staff awareness about Int. standards and Egyptian protocols, also making a shielding mesh in the $\mathrm{CAB}$ roof, providing the communication engineers and workers with personal protection equipments (PPE) protecting them from the harm of EMR.

\section{CONCLUSIONS}

This research is the first of its kind to be carried out in one of the air traffic control towers, where practical measurements of the levels of electromagnetic radiation emitted from radio transmission sources were carried out inside and outside the tower. As a result, dangerous and safe places were located.

Therefore, procedures for the safety and protection of workers and to provide a safe workplace safe from the electromagnetic radiation (EMR) risks will be applied .

This study concluded that most of the areas inside the ATCT meet the safe standards 
except the top roof area where, antenna exist.

The main effect of exposure to

RF/MW fields is heating of body tissues as energy from the fields is absorbed by the body, prolonged exposure leads to heat stroke and damage organs, specific thermal effects as ocular effects and auditory effects, nonthermal effects as nervousness, irritability, headache, depression, sleeplessness, altered cell membrane permeability, behavioral effects, and others.

A questionnaire showed that most of the staff are concerned of EMR in the tower and thought that the EMR has adverse health effect.

This study recommends that the employer (NANSC) must have policy and program for EMR safety, there is no policy or program yet, establish a medical screening program for early detection of EMR health effects on workers. modifying and upgrading Egyptian protocols and raising staff awareness about International standards and Egyptian protocols. It recommends, also, making a shielding mesh in the $\mathrm{CAB}$ roof and providing the communication engineers and workers with personal protection equipment (PPE) to protect them from the EMR and provides the tower facility with EMR first aid.

\section{REFERENCES}

1.Department Of Transportation (2004):

Airport Traffic Control Tower and Terminal Radar Approach Control Facility Design Guidelines. Federal Aviation Administration.

2.Guyer J and P.E. (2015): An Introduction to Air Traffic Control Facilities. Fellow
ASCE (American Society of Civil Engineers), Fellow AEI (Architectural Engineering Institute).

3.Robert W(2013): Organization and Innovation In Air Traffic Control, Jr. Hudson Institute.

4. Radio_Spectrum-2016.pdf.

5. ITU-R Recommendation V.43, Nomenclature of the frequency and wavelength bands used in telecommunications, International Telecommunication Union, Geneva. (Web site: http://www.itu.int/rec/R-RECV.431/en).

6. IEEE Standard 521-2002: Standard Letter Designations for Radar-Frequency Bands.

7. RF Radiation Measurements in Selected Locations in Kokomo, Indiana, by Bill P. Curry, Ph.D. and Gretchen V. Fleming, Ph.D., Prepared for Acentech, Inc. Cambridge, MA, August 29, 2003

8. Tomasz Dlugosz, Hubert Trzaska, How to Measure in the Near Field and in the Far Field, Communication and Network, 2010, 2, 65-68

9. Soichi WATANABE and Lira HAMADA, Measurements of the Electromagnetic Field from a Mobile Phone Base Station, Journal of the National Institute of Information and Communications Technology Vol. 63 No. 1 (2016)

10. A K M Fazlul Hoque, Md. Sazzad Hossain, A Sattar Mollah, Md. Akramuzzaman, A study on specific absorption rate (SAR) due to non-ionizing radiation from wireless/telecommunication 
in Bangladesh, American Journal of Physics and Applications, Vol. 1, No. 3, 2013, pp. 104-110. doi : 10.11648/j.ajpa.20130103.18

11. Opinion on Possible Effects of Electromagnetic Fields (EMF), Radio Frequency Fields (RF) and Microwave Radiation on Human Health, Scientific Committee on Toxicity, Ecotoxicity and the Environment (CSTEE).

12.John E.: Electromagnetic Fields and Human Health, Professor of Radiation Oncology.

Ankur Mahajan, Mandeep Singh, Human

Health and Electromagnetic Radiations, International Journal of Engineering and Innovative Technology (IJEIT) Volume 1, Issue 6, June 2012 IJEIT1412201206_18.pdf.

13.Ali Zamanian and Cy Hardiman, Fluor Corporation, Industrial and Infrastructure Group, Electromagnetic Radiation and Human Health: A Review of Sources and Effects, From July 2005 High Frequency Electronics Copyright (C) 2005 Summit Technical Media,HFE0705_Zamanian.pdf

14. Adlina Suleiman, Thor Teong Gee, Ambigga Devi Krishnapillai, Khalifah Mohamad Khalil, Mohammad Wisman Abdul Hamid, Marami Mustapa, Electromagnetic Radiation Health Effects in

Exposed and Non-Exposed Residents in Penang, Journal of Geoscience and Environment Protection, 2014, 2, 77-83.

15. Awn B. Rifai, Majed A. Hakami, Health Hazards of Electromagnetic
Radiation, Journal of Biosciences and Medicines, 2014, 2, 1-12

16. Kuldip Singh, Younis Muhammad, Study of the Effects of RF/MW Radiations on Humans, International Journal of Engineering Research and Applications (IJERA) ISSN: $2248-9622$

Vol. 2, Issue 4, July-August 2012, pp.16451648

17. M.Usha Rani, Dr. V.S.S.N. Srinivasa Baba1 and Dr. Srivalli Gundala, Analysis of SAR in Human Blood, Bones and Muscles due to Mobile Waves at $900 \mathrm{MHz}, 1800 \mathrm{MHz}$ and $2400 \mathrm{MHz}$, International Journal of Applied Engineering Research ISSN 0973-4562 Volume 13, Number 5 (2018) pp. 21252129

18. C. S. Wang, G. X. Shen, Relationship among SAR, RF frequency and Tissue, Proc. Intl. Soc. Mag. Reson. Med. 11 (2003)

19. "Standard for Safety Level with Respect to Human Exposure to Radio Frequency Electromagnetic Fields, $3 \mathrm{KHz}$ to 300GHz". IEEE STD (IEEE) C95.1. Oct 2005.

20. International Commission on NonIonizing Radiation Protection, "Guidelines for limiting exposure to time varying electric, magnetic, and electromagnetic fields (up

to 300 GHz)", Health Physics 74 (4), April 1998.

21. A Local Government Official's Guide to Transmitting Antenna RF Emission Safety: Rules, Procedures, and Practical 
Guidance, Federal Communications Commission FCC, June 2, 2000.

22. The National Telecommunication Regulatory Authority of Egypt (NTRA).

23. CST 2014 | CST - Computer Simulation Technology | info@cst.com | www.cst.com.

24. EXTECH Instruments User's Guide RF EMF Strength Meter Model 480836.

25. Microsoft Office Excel 2007.

26. David C. Cassidy; Gerald James Holton; Floyd James Rutherford (2002). Understanding physics. Birkhäuser. pp. 339 ff. ISBN 0-387-98756-8.

27. Federal Communications Commission, Office of Engineering \& Technology,
Evaluating Compliance with FCC

Guidelines for Human Exposure to

Radiofrequency Electromagnetic Fields, OET Bulletin 65 (Edition 97-01).

28. Practical Antenna Handbook Fourth Edition Joseph J. Carr, Copyright @ 2001 by The McGraw-Hill Companies.

29. Antenna Theory Analysis and Design, Third Edition, Constantine A. Balanis.

30. Compilation of the Dielectric Properties of Body Tissues at RF and Microwave Frequencies, Camelia Gabriel, U.S. Air Force, Report AFOSR-TR-96. 


\section{تثفيف المغاطر الماهبة لإنبعاثات الإثعاع الكهرومغناطيسى على العاملتن فى برج المراقبة

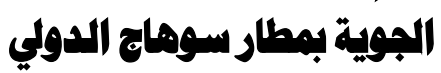

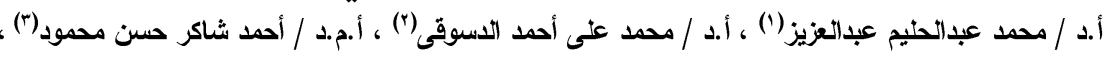

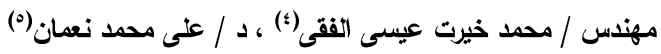

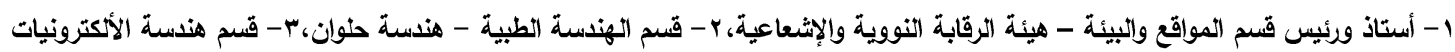

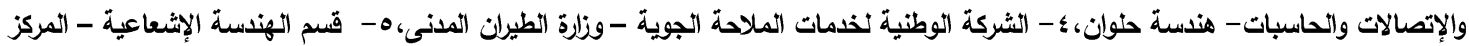

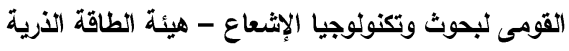

المنص العربي :

من الهم وظائف برج المراقبة الجوية فى المطارات مراقبة الحركة الجوية وتنظيمها ومنع حوادث التصادم بين الطائرات ويعضها البعض على أرض المهبط ويينها ويين المركبات كنلك وإيضا بين الطائرات فى المجال الجوى. جميع تلك الخدمات يتم تقديمها بواسطة ضباط المراقبة الجوية للطائرات من خلال أنظمة الإتصالات بيرج المراقبة الجوية والمساعدات الملاحية.

هوائى الإرسال الخاص بنظام الاتصالات والموجود أعلى مقصورة البرج يبث الموجات الكهرومغناطيسية فى جميع الإتجاهات وتلكك الموجات نها تأثيرات صحية سلبية على العاملين ببرج المراقبة الجوية ويتعامل هذا البحث مع تأثيرات الإثعاع الكهرومغتاطيسى على العاملين فى برج المراقبة الجوية بمطار سوهاج الدولى بإستخدام برنامج على الحاسب الآلى S tudio CST s الكهربى والمغناطيسى وكثافة القدرة بأماكن متتوعة بموقع البحث داخل وخارج البرج ومقارنة تلك النتائج مع المعايير العالمية والمحلية بعمل جداول و رسوم بيانية بإستخدام برنامج Y V Microsoft Excell . . V كنلك تم إجراء القياسات العملية داخل البرج وأعلى سطحه والمنطقة حوذله بإستخدام جهاز قياس meter RF EMF strength من نوع EXTECH الهذف الرئيسى ثهذا البحث هو تخفيف تعرض العاملين للمخاطر من الإثعاع الكهرومغتاطيسى وحمايتهر من تأثيراته السلبية عليهر. وخلصت هذه الدراسة إلى أن معظم الأماكن داخل مبنى برج المراقبة الجوية تتفق مع معايير السلامة ما عدا منطقة أعلى مقصورة البرج حيث يوجد هوائى الإرسال وأظهر الإستبيان أن طاقم العاملين بالبرج قثق بسبب الإشعاع الكهرومغناطيسى بالبرج ويعتقدن انه يسبب تأثثرات صحية سلبية عليهم وأنه حلا لمشكلة تأثير الإثعاع الكهرومغناطيسى على العاملين بالبرج نرى أنه يجب عمل برنامج للسلامة وإحماية من مخاطر التأثيرات المصاحبة للإثعاع الكهرومغناطيسى ويقوم على تنفيذ هذا البرنامج وتطبيقه شخص مؤهل ومتخصص فى هذا المجال وتثتمل طريقة الحماية والتخفيف من مخاطر الإثعاع الكهرومغناطيسى على عدة عناصر من أجل التحكم فى تلتك المخاطر وهى التحكم الهندسى الذى يشمل على تعديلات فى المبنى والأجهزة مصدر الإشعاع الكهرومغتاطيسى و التحكم الإدارى الذى يثمل على تغييرات فى طرق آداء العمل وسياسات العمل واستخدام وسائل التوعية كالعلامات الإرشادية والتحذيرية والتدريب على البرنامج واستخدام أدوات الحماية الثخصية للإثعاع الكهرومفتاطيسى على العاملين وكذلك يلزم عمل برنامج للفحص الطبى الدورى للعاملين للكشف 